\title{
Culture-dependent and culture- independent characterization of bacterial community diversity in different types of sandy lands: the case of Minqin County, China
}

Yali Wei ${ }^{1}$, Fang Wang ${ }^{1}$, Jiangli Gao ${ }^{1,2}$, Yaolong Huang ${ }^{1}$, Wei Ren ${ }^{3}$ and Hongmei Sheng ${ }^{1 *}$

\begin{abstract}
Background: Minqin is suffering from a serious desertification, whereas the knowledge about its bacterial community is limited. Herein, based on Nitraria tangutorum and Haloxylon ammodendron from Minqin, the bacterial community diversities in fixed sandy land, semi-fixed sandy land and shifting sandy land were investigated by combining with culture-dependent and culture-independent methods.

Results: Minqin stressed with high salinity and poor nutrition is an oligotrophic environment. Bacterial community in Minqin was shaped primarily by the presence of host plants, whereas the type of plant and sandy land had no marked effect on those, which displayed a better survival in the rhizospheres of $\mathrm{N}$. tangutorum and $\mathrm{H}$. ammodendron. The dominant groups at phyla level were Actinobacteria, Firmicutes, Proteobacteria, Bacteroidetes, Planctomycetes, Chloroflexi, Acidobacteria and Candidate_division_TM7. The abundance of Firmicutes with ability of desiccationtolerance was significantly higher in harsh environment, whereas Bacteroidetes were mainly distributed in areas with high nutrient content. The abundances of Proteobacteria and Bacteroidetes were relatively high in the rhizospheres of $N$. tangutorum and $\mathrm{H}$. ammodendron, which had more plant-growth promoting rhizobacteria. A large number of Actinobacteria were detected, of which the most abundant genus was Streptomyces. The physicochemical factors related to the diversity and distribution of the bacterial community were comprehensively analyzed, such as $\mathrm{pH}$, electrical conductivity, soil organic matter, $\mathrm{C} / \mathrm{N}$ and sand, and the results indicated that Minqin was more suitable for the growth of $\mathrm{N}$. tangutorum, which should be one of most important sand-fixing plants in Minqin.

Conclusions: The bacterial community diversities in different types of sandy lands of Minqin were comprehensively and systematically investigated by culture-dependent and culture-independent approaches, which has a great significance in maintaining/restoring biological diversity.
\end{abstract}

Keywords: Desertification, Rhizosphere, Sandy land, Bacteria community, Culture-dependent method, Cultureindependent method, Minqin Desert

\footnotetext{
* Correspondence: shenghongm@lzu.edu.cn

${ }^{1}$ Ministry of Education Key Laboratory of Cell Activities and Stress Adaptations, School of Life Sciences, Lanzhou University, Lanzhou, China

Full list of author information is available at the end of the article
}

(c) The Author(s). 2021 Open Access This article is licensed under a Creative Commons Attribution 4.0 International License, which permits use, sharing, adaptation, distribution and reproduction in any medium or format, as long as you give appropriate credit to the original author(s) and the source, provide a link to the Creative Commons licence, and indicate if changes were made. The images or other third party material in this article are included in the article's Creative Commons. licence, unless indicated otherwise in a credit line to the material. If material is not included in the article's Creative Commons licence and your intended use is not permitted by statutory regulation or exceeds the permitted use, you will need to obtain permission directly from the copyright holder. To view a copy of this licence, visit http://creativecommons.org/licenses/by/4.0/ The Creative Commons Public Domain Dedication waiver (http://creativecommons.org/publicdomain/zero/1.0/) applies to the data made available in this article, unless otherwise stated in a credit line to the data. 


\section{Background}

Desertification is a serious global environmental problem [1-3]. China is also under the influence of the desertification, and the areas are mainly concentrated in western of northeast and northwest $[4,5]$. In the northwest China, water resources are dwindling due to years of peripheral expansion by Tengger Desert and Badain Jaran Desert to the downstream Shiyang River basin; desertification in Minqin is more and more seriously [6]. Desert plants with adversity resistance can survive and reproduce in unfavorable environments, such as extreme barrenness, drought, saline-alkali and high intensity radiation, which play an important role in maintaining the ecological stability of extremely poor environments and inhibiting the continuous expansion of desertification.

Minqin desertification is one of the birthplaces of desert, encroaching the valuable living space, endangering the existence and development of humankind, and accelerating the expansion of sandstorms to the east. Many researchers have paid much attention on reforestation [7, 8], relationship between plants and soil properties [9-11], and ecological and hydrological processes $[12,13]$ for the prevention/restoration of desertification. It is well-known that diversity and distribution of soil microbial community vary distinctly in different ecosystems, and the variation is supposed to be related to a series of soil abiotic and biotic factors [14]. Microorganisms are key components in the proper functioning of the ecosystem by the transformation of organic carbon, sulfur, nitrogenous compounds and metals, thereby establishing vegetation and maintaining soil physical structure $[15,16]$. The natural vegetation of Minqin Desert is mainly small shrubs and herbs. Among them, Nitraria tangutorum and Haloxylon ammodendron are the dominant shrubs, and their well-developed roots are conducive to the interaction between plant and microbial community, thus promoting plant growth and improving soil structure [17].

In order to better understand the role of microbes, it is important to increase our knowledge of microbial diversity in a specific environment. However, few reports were about the microbial community structures inhabiting Minqin Desert, especially what factors determine their distribution characteristics. Therefore, it is necessary to investigate the microbial community structure of Minqin Desert, thereby providing important information for desertification control. For this purpose, soil samples of rhizosphere and non-rhizosphere of $N$. tangutorum and $H$. ammodendron from fixed sandy land, semi-fixed sandy land and shifting sandy land in Minqin were collected. The culture-dependent and culture-independent methods were combined to comprehensively evaluate the diversity and distribution of bacterial communities, and preliminarily analyzed the key factors shaping the distribution of bacterial communities. This research will lay a solid foundation for maintaining/restoring biological diversity.

\section{Results \\ Soil properties of sandy lands}

The general physicochemical properties of rhizospheres of two dominant plants and bulk soils from three types of sandy lands of Minqin Desert were summarized in Table 1. The soil $\mathrm{pH}$ was ranged from 8.14 to 9.16. The $\mathrm{pH}$ was significantly different between each sampling site in the fixed sandy land, whereas the difference in other two sandy lands was not significant between their own sampling sites. There was no significant difference in electrical conductivity (EC) of non-rhizospheres from three types of sandy lands, whereas the overall trend of $\mathrm{EC}$ in rhizospheres was higher than that in nonrhizospheres. EC of $N$. tangutorum in fixed sandy land was significantly higher than that in other two sandy lands. Additionally, the content of soil $\mathrm{Na}^{+}$was ranged from 101.18 to $444.33 \mathrm{mg} / \mathrm{kg}$. The contents of $\mathrm{Na}^{+}$from $N$. tangutorum rhizosphere in fixed and shifting sandy lands were significantly higher than that from other sites, whereas the content of $\mathrm{Na}^{+}$from $H$. ammodendron rhizosphere in semi-fixed sandy land was significantly higher than that from other sites. Soil total carbon (STC) displayed significant differences between different sites (ranged from 0.293 to $0.921 \mathrm{~g} / \mathrm{kg}$ ), but still at a low level. Except for the rhizosphere and non-rhizosphere of $N$. tangutorum in fixed sandy land, the differences of soil total nitrogen (STN) among other sites were not significant. $\mathrm{C} / \mathrm{N}$ was significantly different in $N$. tangutorum rhizosphere from different types of sandy lands, whereas there was no obvious change in other samples. The contents of soil organic matter (SOM) in the bulk soils were as follows: fixed sandy land > semi-fixed sandy land $>$ shifting sandy land, which had a significant difference between each other. The content of SOM in rhizosphere of $N$. tangutorum from shifting sandy land was the highest (shifting sandy land > semi-fixed sandy land > fixed sandy land), whereas there was no significantly different between those in rhizospheres of $N$. tangutorum from fixed and semi-fixed sandy lands. The contents of SOM in rhizosphere of $H$. ammodendron were as follows: semi-fixed sandy land > shifting sandy land > fixed sandy land, whereas there was no significantly different between these in rhizosphere of $H$. ammodendron from semi-fixed and shifting sandy lands, and the SOM contents from $H$. ammodendron rhizosphere in semi-fixed and fixed sandy land were all more than those in control samples. Additionally, the soil texture in different sampling sites also displayed significantly different, such as sand (Table 1). 


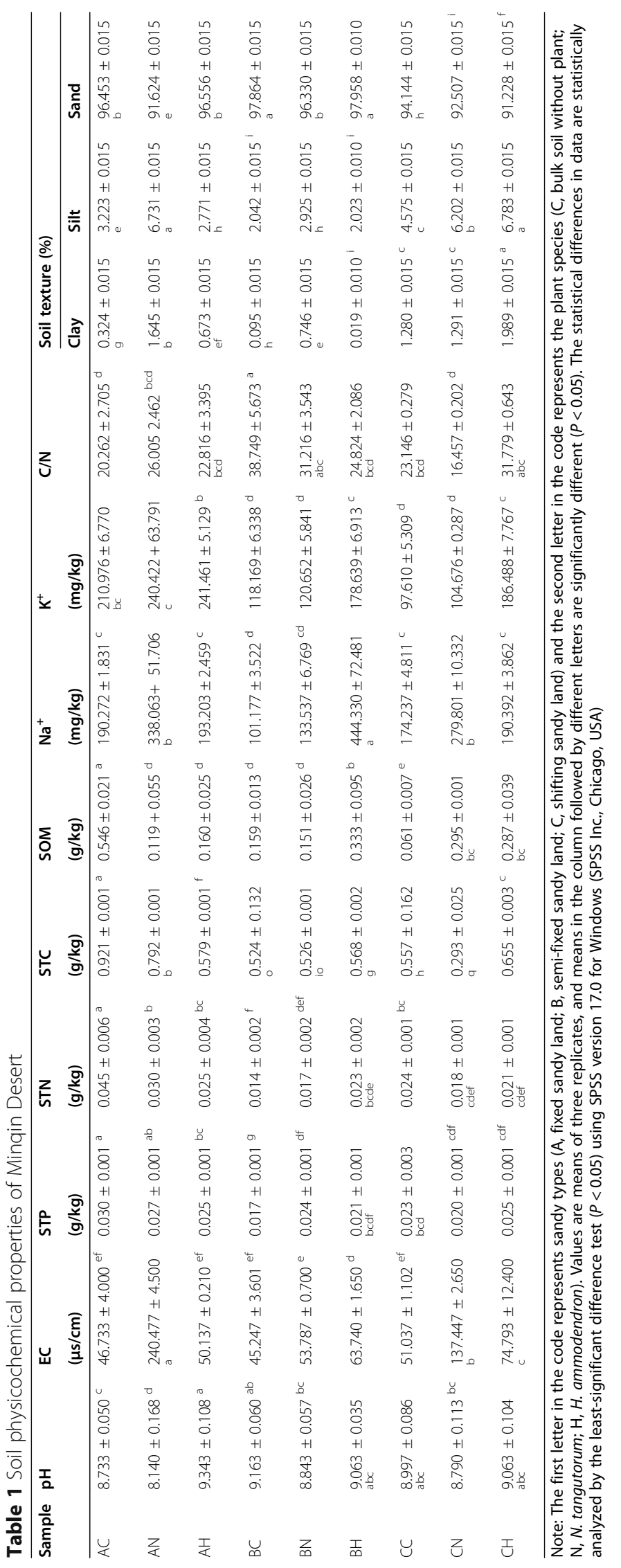




\section{Analysis of diversity and distribution of bacterial community by culture-dependent method}

Seventy-seven morphologically divergent bacterial strains were isolated with reasoner's $2 \mathrm{~A}$ agar $\left(\mathrm{R}_{2} \mathrm{~A}\right.$; Table $\left.\mathrm{S} 1\right)$, and the bacterial count varied from $6.5 \times 10^{4}$ to $4.04 \times 10^{7}$ $\mathrm{CFU} / \mathrm{mL}$. Nineteen genera belonged to four phyla, Actinobacteria, Firmicutes, Proteobacteria and Bacteroidetes (Fig. 1). Bacterial diversity was found to be maximum (up to $80.77 \%$ ) in the phylum of Actinobacteria, and the largest genus was Streptomyces, followed by Pontibacter from Bacteroidetes (5.9\%) only isolated from $H$. ammodendron rhizosphere in fixed sandy land. The relative high abundance of culturable bacterial community in shifting sandy land, especially $N$. tangutorum in shifting sandy land, may give an explanation of why $N$. tangutorum shown the best growth status with the largest abundance of bacterial community. Streptomyces, Arthrobacter, Lysobacte, Sinorhizobium and Bacillus were isolated from the cultivable bacteria community of rhizospheres in semi-fixed sandy land, which were more balance and most of them were plant growth-promoting rhizobacteria. The relative abundance of culturable bacterial community of bulk soil in shifting sandy land was larger than that in other two types of sandy lands. However, the similarity between some bacteria and the closest species was less than $99 \%$ by BLAST analysis of the $16 \mathrm{~S}$ rDNA gene sequences, which indicated that there may be some potential novel species (Table S1). It's worth noting that we didn't find observed colonies in the dark for 3 days at $28^{\circ} \mathrm{C}$ by culture-dependent method, and the observed colonies can be found in the dark for 57 days at $28^{\circ} \mathrm{C}$. We reason that the bacteria from the desert have lower activities than that from other places.

\section{Analysis of diversity and distribution of bacterial community by culture-independent method Overview of diversity and distribution of bacterial community}

Species accumulation curve (SAC) is used to estimate the number of operational taxonomic units (OTUs) in a particular area, which is a tool used to investigate the species composition of the samples and predict their species richness. In the present study, SAC was used to determine whether the observed bacterial diversity represented the overall bacterial diversity. As shown in Fig. S1, SAC was increasing and negatively accelerated, which tended to an asymptote, indicating that the sequencing results were available, and could reflect the bacterial community structure composition of the real samples.

In total, 382,306 quality sequences were obtained from all of the 27 samples with three replicates, and 10,50517,126 sequences were obtained from per sample (mean $=14,159)$. The read lengths ranged from 396.22 to $397.15 \mathrm{bp}$ with an average of $396.50 \mathrm{bp}$. The dominant groups (relative abundance $>5 \%$ ) across all soil samples were Actinobacteria, Firmicutes, Proteobacteria, Bacteroidetes, Planctomycetes, Chloroflexi, Acidobacteria and Candidate_division_TM7 (Fig. 2). These groups accounted for more than $94 \%$ of the bacterial sequences, which was agreed with that from Sonoran Desert soils [18]. Reportedly, the most dominant group in Tenggeli Desert was Proteobacteria phylum [4]. Groups of Caldiserica, Candidate division_OD1, Tenericutes, Thermotogae, WCHB1-60, Deferribacteres, Fibrobacteres, TM6, BHI80-139, Caldiserica, SHA-109, Elusimicrobia, JL-ETNP-Z39, Chlorobi and

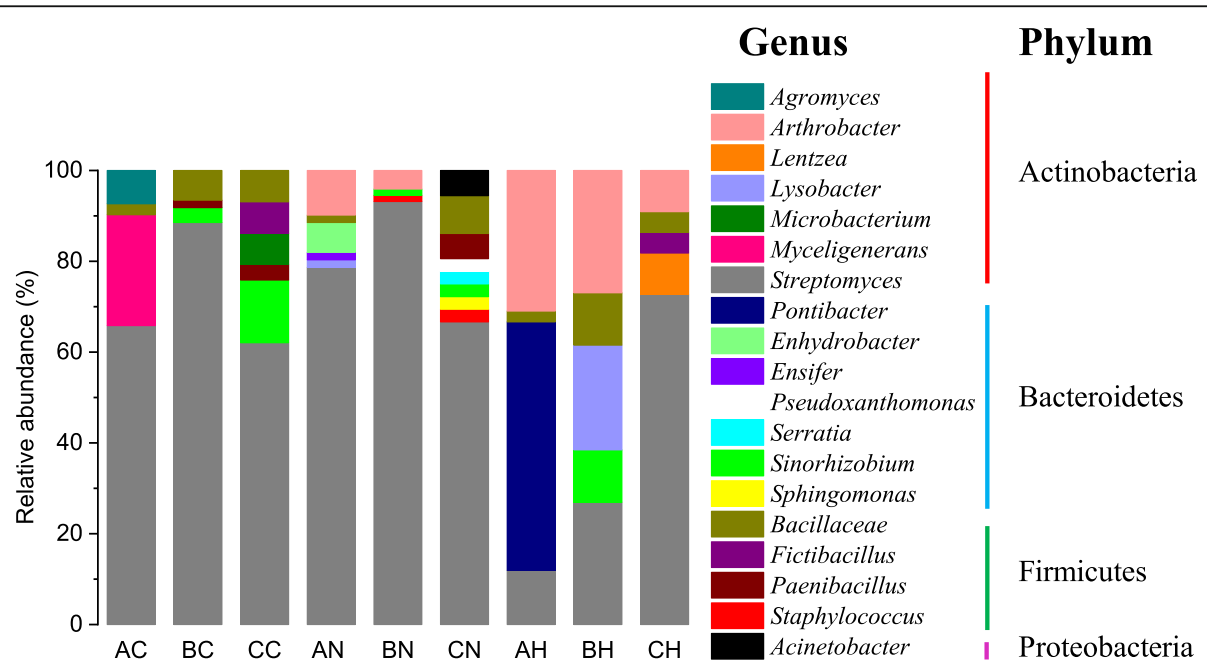

Fig. 1 Distribution of partial sequences of culturable bacteria from bulk soils and rhizospheres of $N$. tangutorum and $H$. ammodendron at fixed sandy land, semi-fixed sandy land and shifting sandy land on the level of genus, and all genera belonged to Actinobacteria, Firmicutes, Proteobacteria and Bacteroidetes. The first letter in the code represents sandy types ( $A$, fixed sandy land; B, semi-fixed sandy land; $C$, shifting sandy land) and the second letter in the code represents the plant species (C, bulk soil without plant; N, N. tangutorum; H, H. ammodendron) 

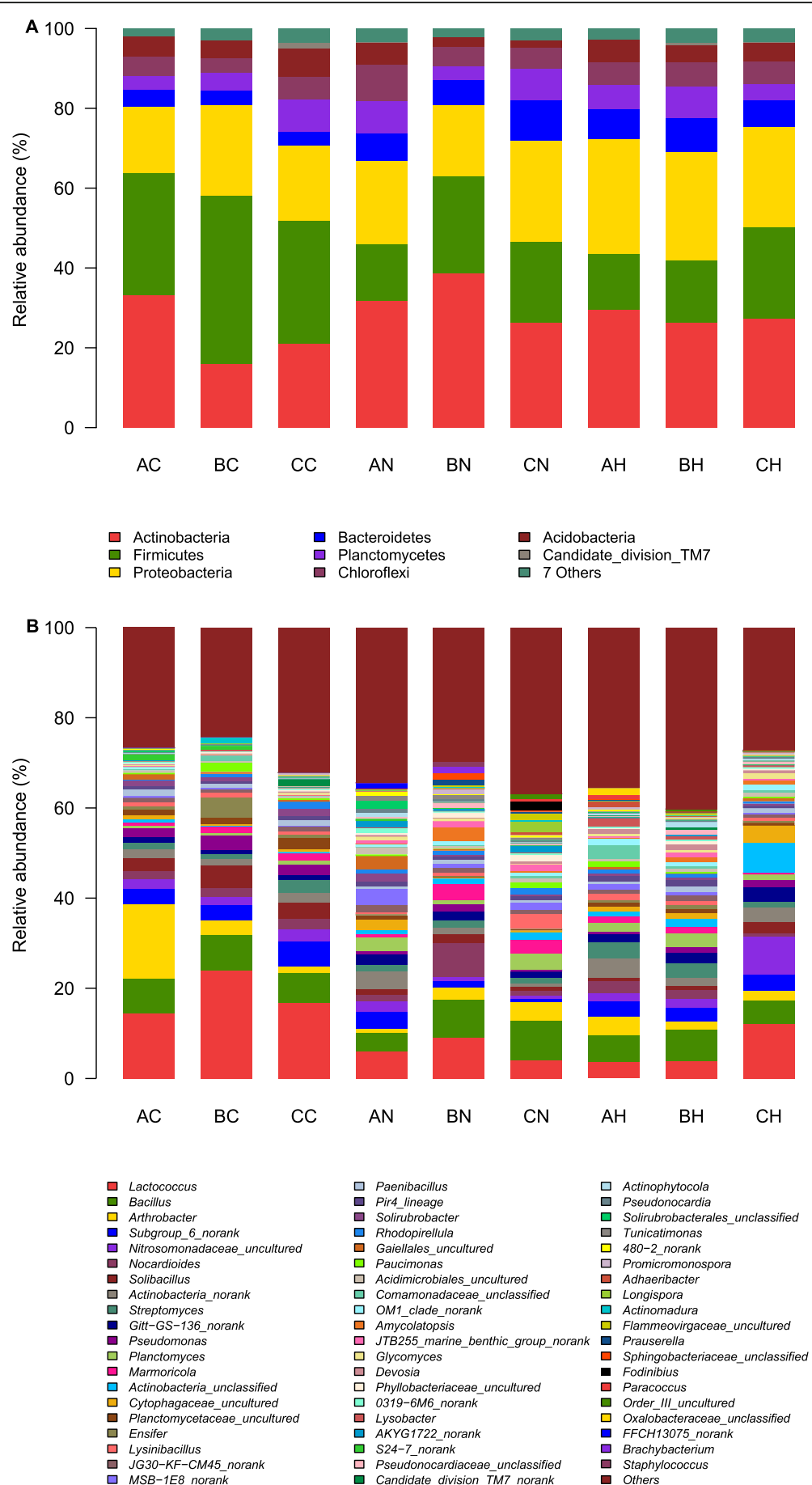

Fig. 2 Relative abundances of the dominant bacterial groups in all soils on the level of phylum (a) and genus (b). The first letter in the code represents sandy types (A, fixed sandy land; B, semi-fixed sandy land; C, shifting sandy land) and the second letter in the code represents the plant species (C, bulk soil without plant; N, N. tangutorum; H, H. ammodendron)

Nitrospirae displayed less abundant (relative abundance > $0.1 \%$ ), but were still found in most desert soils. We found that the phylum distribution in Minqin still had a relative peculiar pattern. Actinobacteria was the most abundant phylum in most of the analyzed samples with the exception of bulk soils from semi-fixed and shifting sandy lands, whereas Firmicutes was the most abundant phylum from semi-fixed and shifting sandy lands. The relative abundance of Bacteroidetes was larger in shifting sandy land of $N$. tangutorum, unfortunately, we didn't isolate Bacteroidetes by 
culture-dependent method. Lactococcus was accounted for the most in the bacterial community distribution of Minqin Desert, especially in non-rhizosphere soil samples, followed by Bacillus. According to the distribution of plants, N. tangutorum in shifting sandy land had higher stress resistance, whereas $H$. ammodendron had better growth status in fixed and semi-fixed sandy land.

\section{Relationship between bacterial community distribution and} type of sandy land and host plant

The results of clustering of rhizospheres and bulk soils by principal component analysis (PCA) showed that OTUs in rhizospheres and bulk soils were clearly separated, whereas there were no large differences between the OTUs of the rhizospheres of $N$. tangutorum and $H$. ammodendron (Fig. 3a). However, no significant differences were observed in the OTUs clustering of the bulk soils, although the compositions of the bulk soils from three types of sandy lands were different (Fig. 3b).

\section{Similarity and difference in the distribution of bacterial community}

Overall, the highly abundant bacteria in rhizospheres at the phylum level can be well clustered, whereas those in bulk soils were in separate groups. The bacterial communities of bulk soils had a large different from those of the rhizospheres of H. ammodendron and N. tangutorum.

In fixed sandy land (Fig. 4a), the relative abundances of BHI80-139, Chloroflexi, Deinococcus-Thermus, Proteobacteria and Bacteroidetes had large numbers in bulk soils and rhizospheres of $H$. ammodendron and $N$. tangutorum, whereas bulk soils than rhizospheres had more Firmicutes. Actually, though the relative abundances of these phyla were similar, the bacterial communities in the two rhizospheres still had a little difference. Deinococcus-Thermus as a thermophilic bacterium displayed a higher abundance in rhizosphere of $N$. tangutorum, which can be commonly isolated from arid and hot deserts.

In semi-fixed sandy land (Fig. 4b), Bacteroidetes, Acidobacteria and Chloroflexi showed higher abundance in rhizosphere of $H$. ammodendron than those in bulk soil and rhizosphere of $N$. tangutorum. Deinococcus-Thermus and Actinobacteria still displayed the largest number in rhizosphere of $N$. tangutorum in semi-fixed sandy land.

In shifting sandy land, numbers of stress-resistant bacteria were found in rhizosphere of $H$. ammodendron, such as Thermotogae and Caldiserica (Fig. 4c). It is worth noting that Deinococcus-Thermus still displayed in rhizosphere of $N$. tangutorum. Additionally, the number of Bacteroidetes was the largest in rhizosphere of $N$. tangutorum, which is often used as one of indications for good soil environment. The rhizosphere of $N$. tangutorum provided the good conductions for the survival of the Bacteroidetes. At the same time, the distribution of Acidobacteria in the rhizosphere of N. tangutorum was significantly higher than that in fixed and semi-fixed sandy lands. Acidobacteria could improve the $\mathrm{pH}$ of rhizosphere, which is beneficial to the growth of plants.
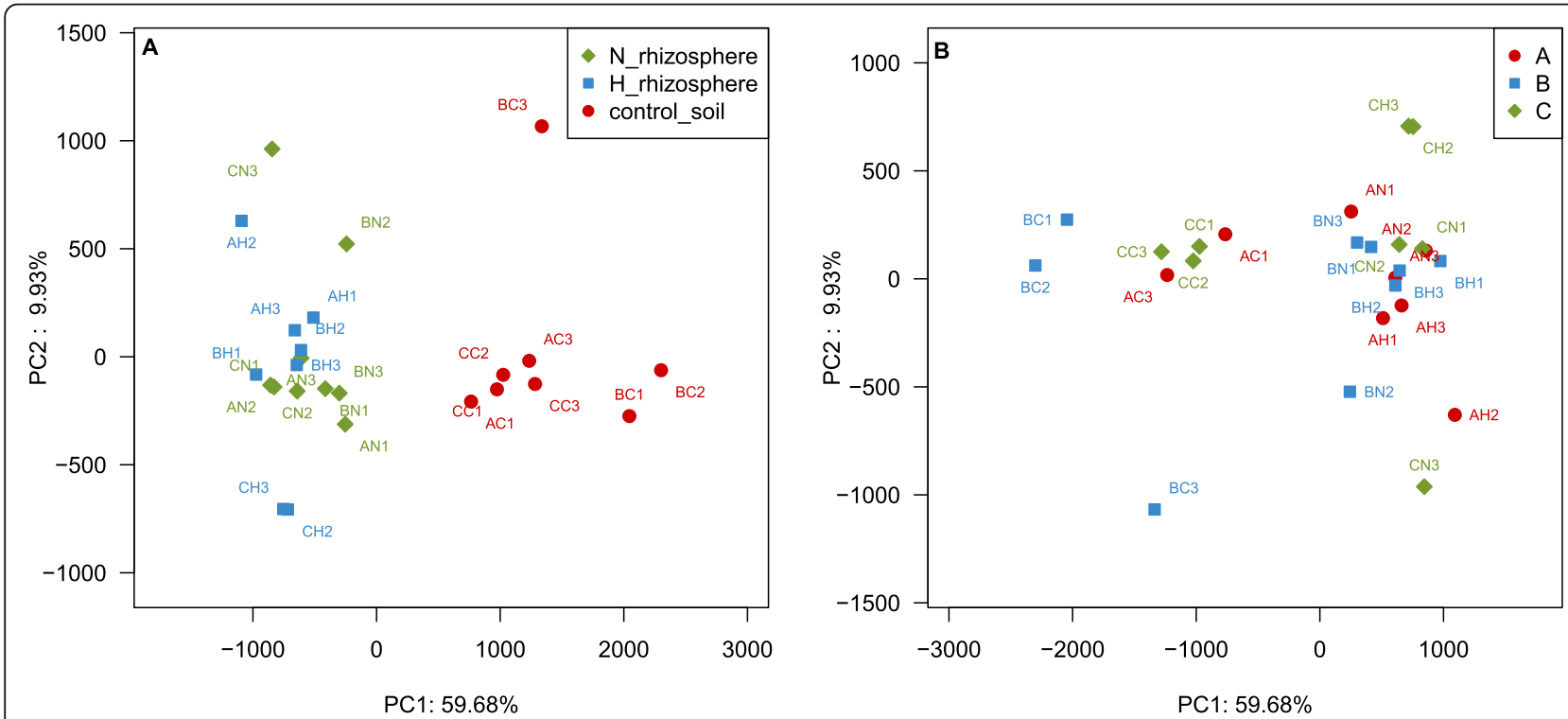

Fig. 3 PCA of the main factors affecting bacterial community distribution. (a): The effects of plant species on the bacterial community distribution: control soil, bulk soils without plant; N_rhizosphere, rhizospheres of $\mathrm{N}$. tangutorum; H_rhizosphere, rhizospheres of $\mathrm{H}$. ammodendron. (b): The effects of types of sandy lands on the bacterial community distribution: A, fixed sandy land; B, semi-fixed sandy land; C, shifting sandy land. The first letter in the code represents sandy types and the second letter in the code represents the plant species 

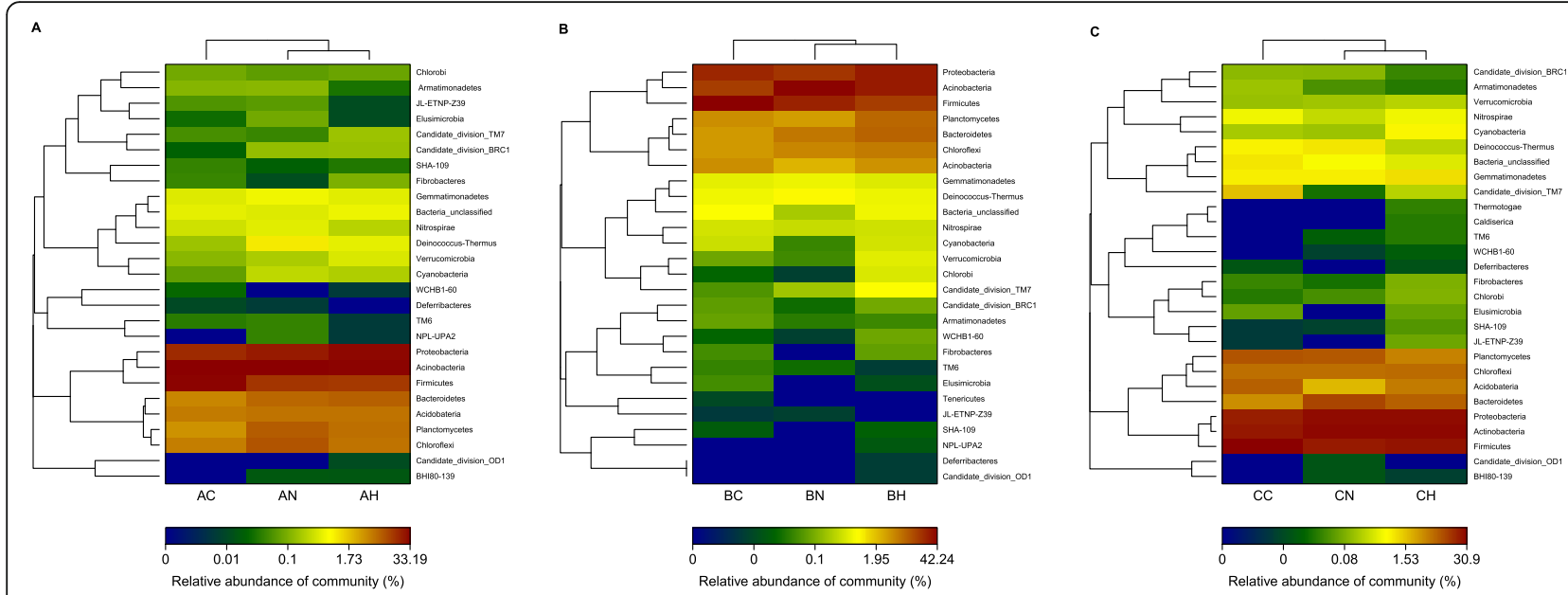

Fig. 4 Distribution heatmap of microbial orders arranged by hierarchical clustering of samples from fixed sandy land (a), semi-fixed sandy land (b) and shifting sandy land (c) at the phylum level. The first letter in the code represents sandy types (A, fixed sandy land; B, semi-fixed sandy land; C, shifting sandy land) and the second letter in the code represents the plant species ( $C$, bulk soil without plant; N, N. tangutorum; H, H. ammodendron)

In conclusion, the physiological growth state of $N$. tangutorum in shifting sandy land was much better than that in other two types of sandy lands.

\section{Comparison of bacterial distribution of rhizospheres and bulk soils}

As shown in Fig. 5a, of the 2034 total observed OTUs from different phyla, 1347 (66.2\%) containing a proportionately large percentage of the raw reads $(199,779$ of the 212,390 reads or $94.1 \%$ ) were found in both soil and rhizosphere of $N$. tangutorum, whereas the bulk soil and rhizosphere harbored only 273 (13.4\%) and 414 (20.4\%) unique OTUs, respectively. Bacteroidetes and Proteobacteria were notably abundant and disproportionately over represented in the rhizosphere of $N$. tangutorum (the bar graphs seen in Fig. 5a). Meanwhile, 2051 OTUs were found in the rhizosphere of $H$. ammodendron and bulk soils, whereas the soil and rhizosphere harbored only $184(8.97 \%)$ and 431 (20.1\%) unique OTUs, respectively (Fig. 5b). The number of OTUs of rhizosphere of $H$. ammodendron showed relative larger than that of the soil-only. However, the both soil and rhizosphere of $H$. ammodendron still had the highest number of OTUs $(70.01 \%)$ with the proportionately large percentage of the raw reads (211,168 of the 218,671 reads or $96.57 \%)$. The predominate unique phylum of rhizosphere of $H$. ammodendron were Actinobacteria, Bacteroidetes and Proteobacteria, whereas the soil-only had large number of Planctomycetes. Among the bacteria in both, Firmicutes was accounted for the highest proportion.

\section{Discussion}

\section{Soil physicochemical properties of Minqin Desert}

The structure of bacterial communities in soil seems to be driven by the physicochemical properties of soil and the type of land [19-22]. On the order of thousands to tens of thousands of kilometers, microbial community structure is correlated to edaphic variables, such as $\mathrm{pH}$, STN, SOM, moisture content and STC [23-25]. Minqin Desert is in alkaline environment. The $\mathrm{pH}$ of fixed sandy land was significantly affected by plants. The fixed effect of plants made fixed sandy land (less affected by wind and sand) form a relatively stable and unique microhabitat with specific $\mathrm{pH}$ environment. Reportedly, $\mathrm{pH}$ of acidic soils almost played a decisive role in bacterial distribution [24, 26]. Additionally, the endophytic bacteria in sugarcane diversity was mainly affected by soil $\mathrm{pH}$ and clay [27]. The trend of EC in rhizospheres was higher than that in non-rhizospheres (Table 1), we reason that the exudates and bacteria activities of rhizosphere accelerated the decomposition of organic matter, thereby promoting the absorption of some soluble ions that were beneficial to the root system and creating a suitable osmotic pressure for the survival and reproduction of rhizosphere bacteria. Due to the severe saline-alkali stress in Minqin Desert all the year round, the desert plants and bacterial communities displayed saline-alkali tolerance and antagonistic mechanism to ensure their stable survival and genetic development. $N$. tangutorum with higher EC in fixed sandy land had a wide tolerance range for saline-alkali stress. This may be the reason why $N$. tangutorum was more adaptable to saline-alkali environment. The rhizosphere of $N$. tangutorum and $H$. ammodendron displayed high content of $\mathrm{Na}^{+}$(Table 1), indicating that high content of $\mathrm{Na}^{+}$didn't limit the growth of plants lived in saline soils for long periods of time. $N$. tangutorum absorbed $\mathrm{Na}^{+}$as inorganic osmotic regulator by root system, thereby adapting to saline-alkali environment [28]. Reportedly, the 


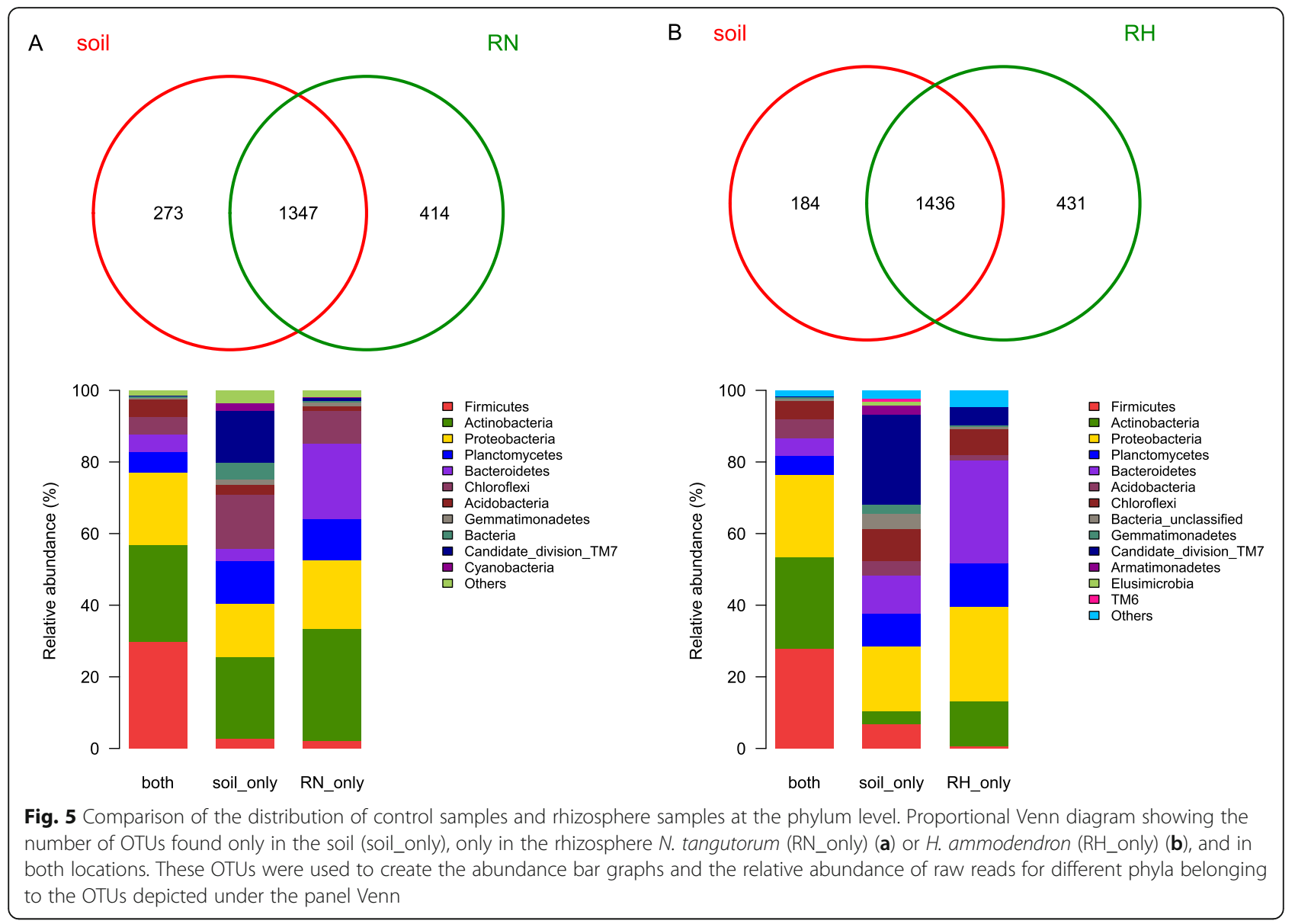

content of $\mathrm{Na}^{+}$in Namib Desert had greatly influence on the distribution of bacteria [29]. The SOM distribution in Minqin Desert suggested that the SOM of nonrhizosphere was affected by soil crust, which showed higher SOM in fixed sand land (Table 1). SOM distribution of rhizosphere might be affected by secretion or microorganism, which was consistent with the growth state of plants. In addition, the contents of SOM were significantly different between each type of sandy land, and between those in rhizospheres of $N$. tangutorum and $H$. ammodendron (Table 1). Our research matched the resource island hypothesis in semi-fixed and shifting sandy land, which depended on the growth status of the shrubs. The decrease of shrub coverage and productivity maybe due to the decrease of deep soil water content $[9,30,31]$, which gave a strong evidence for that why $N$. tangutorum under long closed fences is still at risk of death on fixed sand. Overall, Minqin Desert was stressed with high salinity and poor nutrition, which was an oligotrophic environment.

Detection of bacterial community of rhizosphere and bulk soils at different habitats by culture-independent method Independent techniques provide an opportunity to study a much broader spectrum of microorganisms in the rhizosphere, which can be used for detecting structure and function of rhizosphere communities. The dominant groups in Minqin included Actinobacteria, Firmicutes, Proteobacteria, Bacteroidetes, Planctomycetes, Chloroflexi, Acidobacteria and Candidate_division_TM7 according to the results of culture-independent sequencing (Fig. 2), which were similar to that in Sonoran Desert, Tenggeli Desert and Brazilian Caatinga Biome [4, 18, 32]. A high abundance of Proteobacteria has previously been associated with high availability of carbon [33-35]. Acidobacteria can well grow in oligotrophic conditions [36] and is an indicator of the acidic conditions [37, 38]. Minqin Desert is stressed with poor nutrition, and its soil $\mathrm{pH}$ displayed significant differences in different sites (Table 1), which maybe the justification that the actinomycetes population varied as per sampling site. Therefore, Actinobacteria and Firmicutes with high abundance in Minqin as the certain bacterial phyla, similar to Proteobacteria and Acidobacteria, may be used as indicators of nutrient status owing to their lifestyles. Additionally, some phyla related to heat resistant and documented radiotolerance, such as Thermotogae, Caldiserica and Deinococcus-Thermus, were detected in Minqin Desert. Generally, the bigger proportion of Bacteroidetes, the 
more fertile of soil. The phylum of Bacteroidetes is always dominant part in some black glebes, even in semi-moist desert [26], and the abundance of this phylum in Minqin Desert also displayed relatively high. The abundances of Proteobacteria and Bacteroidetes were relatively high in the rhizosphere of $N$. tangutorum from shifting sandy land and $H$. ammodendron from semi-fixed sandy land, and the both shrubs showed the best growth status in Minqin. We reason that Bacteroidetes and Proteobacteria have more plant-growth promoting rhizobacteria, and these species were the selection effect of root exudates in rhizosphere. All of these results indicated that shrubs could change bacterial community composition, and the bacterial community in rhizosphere showed a better survival.

The proportion of Lactococcus and Bacillus maybe play an important role in soil restoration, which can promote the formation of polyglutamic acid as a natural protective biofilm for soil, thereby preventing the loss of water and fertilizer. The organic acids and enzymes were synthesized by these bacterial strains, which could furtherly promote the growth of plants by the decomposition of soil macromolecules. In addition to Lactococcus and Bacillus, Arthrobacter known as growth-promoting bacterium also occupied the majority proportion. In our research on plant endophytic bacteria in Minqin Desert, Lactococcus displayed the highest abundance in the bacterial community distribution, and Bacillus and Arthrobacter were also widely distributed. Streptomyces in bulk soil from shifting sandy land with relatively high content was consistent with our results of culturable bacteria. Interesting, Fodinibius was only distributed in N. tangutorum rhizosphere from shifting sandy land in Minqin Desert, which is mostly distributed in ocean and salt lakes. Therefore, we reason that the presence of Fodinibius played a certain role in the saline-alkali stress tolerance of N. tangutorum.

The total number of bacteria in rhizosphere was higher than that in non-rhizosphere, and the number of unique bacteria in rhizosphere was still higher than that in non-rhizosphere according to the results obtained by culture-independent method, indicating that the presence of host plants could promote the increase of the number of bacterial communities, whereas sandy land type was the secondary factor affecting the microbial communities in Minqin sandy lands (Figs. 3 and 4). This result was significantly different with that of the bacterial community structure of the two pine species in a semiarid ecosystem [39]. Some researchers believed that the plant type was the dominate factor for the bacterial community distribution [40,41], whereas some others showed that the soil type was more important for that [42]. The bacteria in both accounted for a large proportion (Fig. 5), indicating that the bacterial community in the same area had a high level of cross-species homology. The distribution of bacterial community is usually affected by complex biological factors and series of abiotic factors. Due to the influence of special climatic characteristics and geographical environment, the growing plants in different study areas are also usually significantly different.

\section{Detection of bacterial community of rhizosphere and bulk soils at different habitats by culture-dependent method} Cultivation-based methods only address the culturable bacteria [43], which are considered to represent only a small proportion $(0.1-10 \%)$ of the total bacteria presented in soil and rhizosphere [44]. Although the cultivable way can't obtain all of the bacterial groups, it also fully predicts the dominant group in the bacterial community [43]. According to the results of high through-put sequencing, Actinobacteria, Firmicutes and Proteobacteria were most abundant phyla, which was similar to that obtained by cultivable way. The $\mathrm{R}_{2} \mathrm{~A}$ medium was more suitable for the growth of Actinobacteria. We reason that spores produced by Actinobacteria were easier to spread, and the production of aerial hyphae and antibiotics can promote the absorption of nutrient in the medium and inhibit the growth of other bacteria. Therefore, the most obtained bacterium in the isolates was Actinobacteria, and the most abundant genus was Streptomyces known as a type of bacteria that can produce antibiotics. Unfortunately, Streptomyces was only isolated by cultivable way. It is worth to notice that the most dominant culturable bacteria of H. ammodendron rhizosphere was Pontibacter korlensis (Fig. 1), which was a kind of radiation and drought resistant bacteria belonged to Ponibacter, and Pontibacter korlensis has been isolated from Xinjiang, China [45]. In the culturable process, due to the limitation of preference of bacteria and nutrients in the culture, some bacteria may grow rapidly and become the dominant groups. Unfortunately, the vast majority of soil microbes are recalcitrant to culturing techniques [46], thereby preventing accurate examination of the diversity and degree of influence between biotic and abiotic factors on soil microbial communities.

Currently, the research methods of plant-associated microbiome mainly include the traditional culturedependent method [47, 48] and culture-independent method (especially high-throughput sequencing) [49, 50]. Although only less than $1 \%$ bacteria of the microbial community could be detected by culture-dependent approach, the living bacteria can be obtained, which is an essential method for various researches $[43,51]$. Surveys of bacterial communities in soil by high-throughput sequencing have illuminated the important edaphic and biotic factors on microbial diversity [18]. Culture-dependent and cultureindependent approaches, despite their own limitations in 
measuring the diversity of microbial community, still give a reasonably great idea of microbial community structure [52]. In this work, the culture-dependent and cultureindependent approaches were combined to systemically study on the bacterial community distribution in Minqin (Fig. S2), which gave a reasonably good idea of microbial community structure. A large number of potential plant growth-promoting bacteria were isolated from Minqin Desert. Further examination of the Minqin Desert microbiome is likely to reveal additional candidates for promoting plant growth in challenged environments. Culturable methods should be continuously improved and mainly used in screening functional strains, such as Nocardiopsis quinghaiensis isolated from high salt conditions in Qinghai, China [53] and Pontibacter salisaro isolated from a clay tablet solar saltern in Korea [54], which provide our future study on screening species-specific bacteria for plant growthpromoting or salt-tolerant. High-throughput way could be used to understand the distribution of bacterial communities, whereas cultivable way could be mainly used for the isolation of special strains.

\section{Correlation analysis between the bacterial communities and environmental factors}

According to the physicochemical characteristics of the soil in Minqin, the distribution of the main bacteria species was analyzed. As shown in Fig. 6, the rhizosphere of $N$. tangutorum had high SOM, and the available STC of plants and bacteria was at a relatively high level. Additionally, clay and silt in soil composition also maintained at a high level. These results indicated that the microhabitat of $N$. tangutorum rhizosphere had been greatly improved, which was a relatively harsh extreme desert environment. At the same time, the higher content of Bacteroidetes also revealed the same trend, which is a sign that the corresponding soil is suitable for biological survival. Minqin was a nutrient-poor region, STN, STC, soil total phosphorus (STP) and $\mathrm{K}^{+}$were all at a low level from each site. Therefore, these nutrients

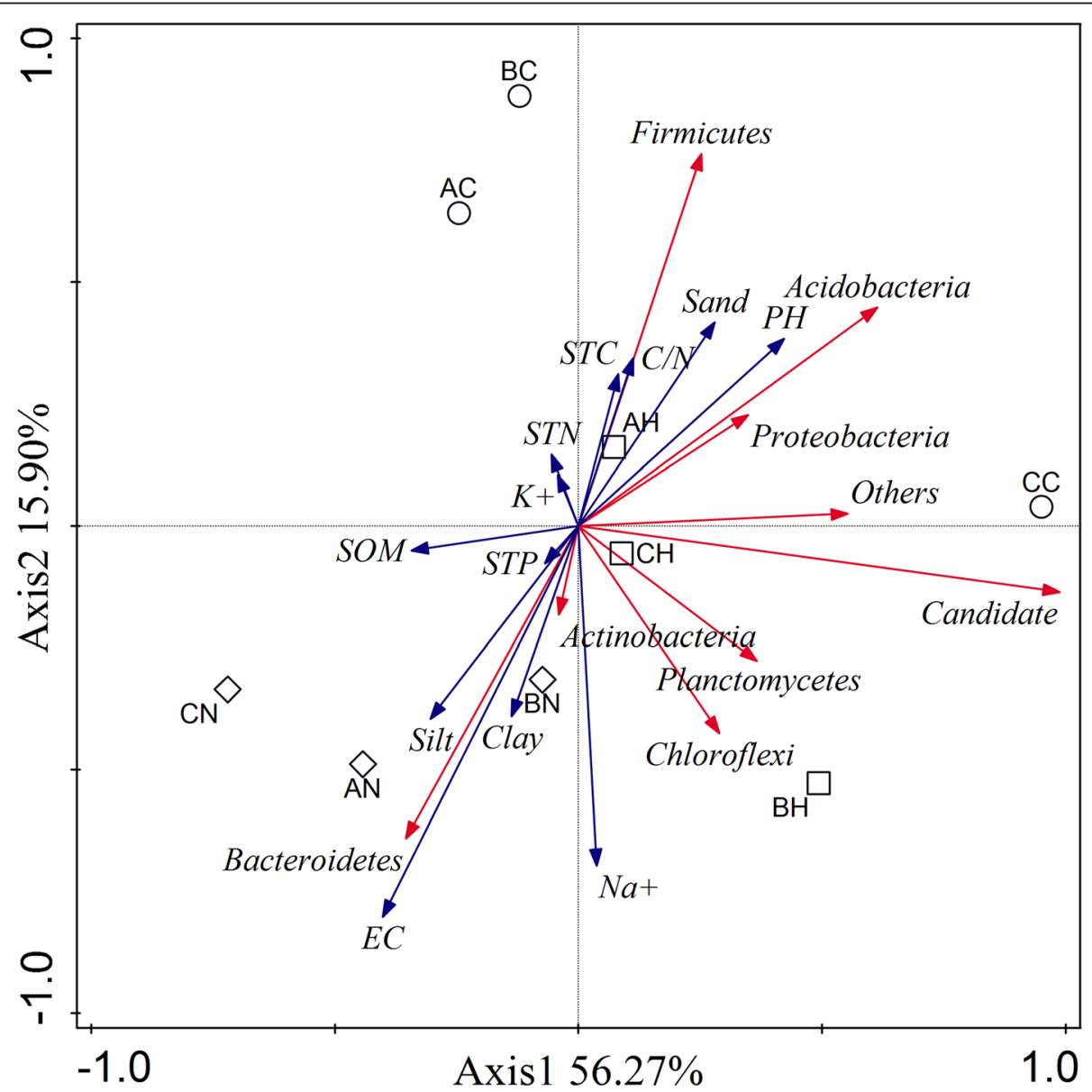

Fig. 6 Redundancy analysis between the bacterial communities and the environmental factors present in the rhizosphere soil and bulk soil in three types of sandy lands. The first letter in the code represents sandy types ( $\mathrm{A}$, fixed sandy land; B, semi-fixed sandy land; $\mathrm{C}$, shifting sandy land) and the second letter in the code represents the plant species ( $\mathrm{C}$, bulk soil without plant; N, N. tangutorum; H, H. ammodendron) 
were not the main reason for differences in bacterial communities in Minqin.

The condition with higher sand and $\mathrm{pH}$ were more suitable for the growth of Firmicutes, and Firmicutes distributed in non-rhizosphere soils can adapt to the harsh environment. Therefore, in order to adapt to saline-alkali environment, Firmicutes is the main pioneer bacteria. With the selection of plant rhizosphere and the change of rhizosphere microenvironment, the proportion of Firmicutes will gradually decrease, and the bacterial diversity will also gradually increase, thereby forming a stable bacteria community structure of perennial rhizosphere. Due to the long-term selection and adaptation, the proportion of some plant associated bacteria, especially the bacteria promoting plant growth, gradually increased, and the rhizosphere bacteria gradually formed their own unique spatial distribution. Therefore, the interaction between bacteria and plants can effectively improve the soil microenvironment and increase the available nutrients in the soil, which is better for the plant growth. Such a virtuous cycle puts forward a feasible scheme for desertification control in the future, which can be applied to the effective control of desertification by artificially adding some promoting agents to promote plant growth and accelerate the improvement and restoration of microenvironment. $N$. tangutorum compared with $H$. ammodendron can more obviously improve rhizosphere environment. Therefore, we reason that Minqin sandy land is more suitable for the growth of $N$. tangutorum, which should be one of most important sand-fixing plants in Minqin.

The physicochemical factors that affect the distribution of bacteria in different environments are different [43]. The physicochemical factors related to the samples in this study were $\mathrm{pH}, \mathrm{EC}, \mathrm{SOM}, \mathrm{C} / \mathrm{N}$ and sand. Reportedly, the main factors affecting the distribution of bacteria in the desert were $\mathrm{pH}$, total carbon, $\mathrm{C} / \mathrm{N}$ and sand, whereas total nitrogen was not a key factor [18]. Nacke and coworkers showed that the main factors affecting the distribution of bacteria were organic carbon content and total nitrogen content in grassland [55]. In Minqin Desert, the rhizosphere of $N$. tangutorum had higher $\mathrm{Na}^{+}$concentration and EC, which may be closely related to the halophilic mechanism of $N$. tangutorum; the composition of soil particles greatly differed between non-rhizosphere and rhizosphere, indicating that with the growth of plants, the proportion of sand particles decreased, and the phenomenon in rhizosphere of $N$. tangutorum was more obvious; the $\mathrm{pH}$ of non-rhizosphere soil was higher than that of rhizosphere, indicating that soil alkalinity was reduced under the effect of vegetation. $\mathrm{SOM}, \mathrm{TOC}$ and $\mathrm{C} / \mathrm{N}$ were significantly related to the bacterial community structure in the bacterial community in Changbai Mountain [56]. Reportedly, the bacterial community structure was mainly affected by carbon content in extreme environments, whereas total nitrogen was not the main factor [56].

Firmicutes, the main phylum adapted to barren and harsh environments, had a very significant positive correlation with sand and $\mathrm{pH}$ (Fig. 6), indicating that Firmicutes was the most dominant bacterial phylum in an alkaline environment. Bacteroides phylum is often regarded as one of soil quality indicator bacteria and indicates restoration in local desert. Bacteroides was densely distributed in rhizosphere of $N$. tangutorum, which was significantly positively correlated with EC, clay and silt, indicating that $N$. tangutorum had an important significance for desert restoration, and the interaction between plants and bacteria also could promote the improvement and restoration of desert in Minqin.

\section{Conclusions}

In the present study, based on two dominate plants, $N$. tangutorum and $H$. ammodendron, twenty-seven samples with three replicates from fixed sandy land, semi-fixed sandy land and shifting sandy land in Minqin Desert were collected to investigate the distribution and diversity of bacterial community by culture-dependent and culture-independent methods. Bacterial community of Minqin Desert was shaped by the presence of host shrubs, whereas the type of the host and sandy land had no significant effect on that. The key factors, $\mathrm{pH}, \mathrm{EC}$, SOM, C/N and sand, related to the distribution of the bacterial communities were preliminary analyzed, of which EC, clay and silt were significantly positively correlated with the distribution of Bacteroides. We also found a large number of strains with specific functions and demonstrated that the important role of $N$. tangutorum in desertification restoration. For example, Lactococcus, Bacillus and Arthrobacter known as growthpromoting bacterium occupied majority proportion; the abundances of Proteobacteria and Bacteroidetes were relatively high in the rhizospheres of two shrubs, which had more plant-growth promoting rhizobacteria; the presence of Fodinibius played a certain role in the saline-alkali stress tolerance of $N$. tangutorum. This study may help the development of a strategy for revegetation management in desertified lands.

\section{Methods}

\section{Study site description and sample collection}

Minqin, which is surrounded by the Badain Jaran Desert and the Tengger Desert, located at the lower reaches of Shiyang River next to Wuwei, Gansu Province, northwest China. The special geographical position is shown in Fig. 7. All soil samples were collected from Minqin County $\left(38^{\circ} 62^{\prime} \mathrm{N}, 103^{\circ} 08^{\prime} \mathrm{E}\right)$. Two dominant desert plants distributed in fixed sandy land, semi-fixed sandy land 


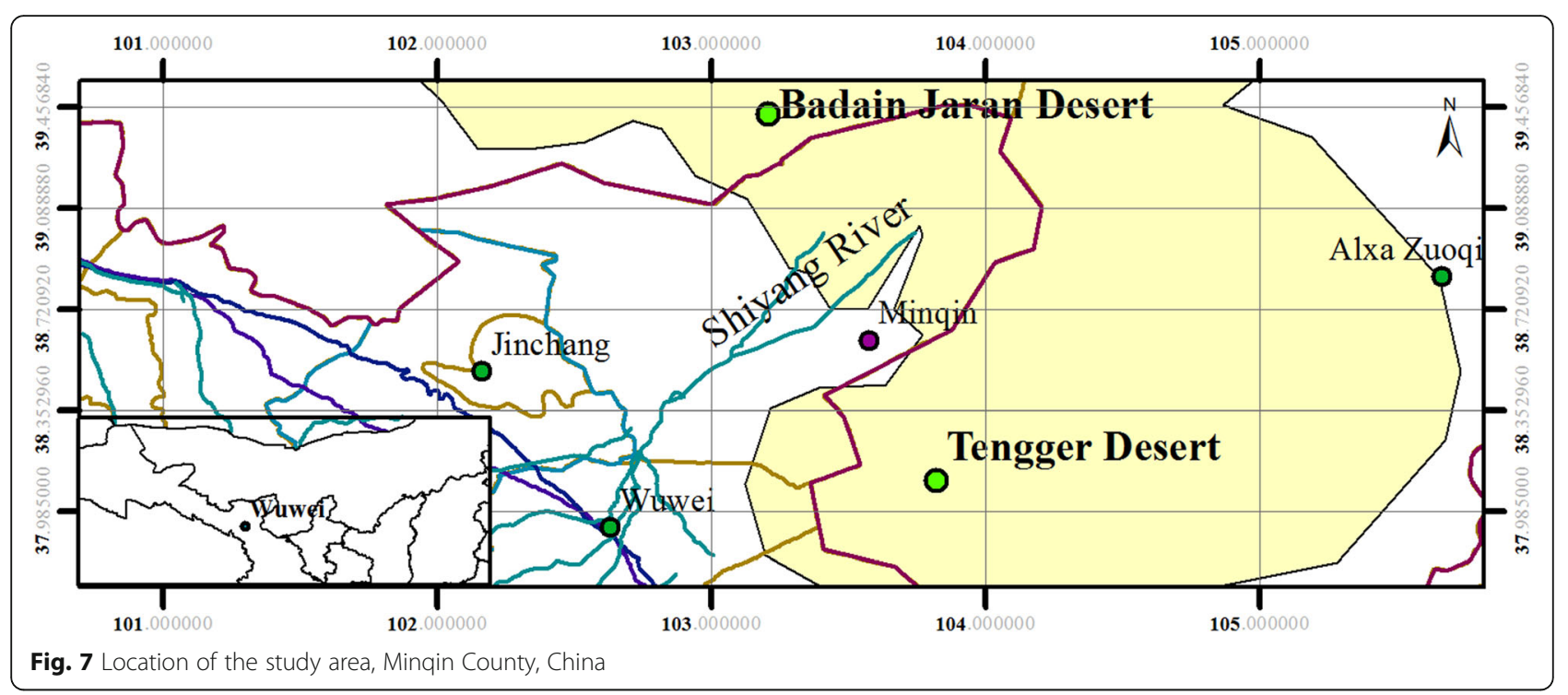

and shifting sandy land, $N$. tangutorum and H. ammodendron, were selected for further study in Minqin. Bulk and rhizosphere soil samples were collected from $N$. tangutorum and $H$. ammodendron at maturity growth stage in three types of sandy lands. The rhizosphere soil was extracted at a soil depth of $50 \mathrm{~cm}$ deep along the roots, and loosely adhering soil was collected as rhizosphere soil [57]. Total 27 samples from 9 sites with three replicates were collected. Each replicate rhizosphere soil sample (approximately $200 \mathrm{~g}$ from each individual) was from three randomly selected adhering soil samples separated from three plants of same type at a distance of 30 to 50 $\mathrm{m}$ between single plants. Bulk soil as the control group, collected from each sandy land without any plant. Each replicate bulk soil sample was from three randomly selected soil samples collected from at a distance of about $200 \mathrm{~cm}$ from the sampling plants. All of the samples were without roots and from the same depth. The aluminium boxes were used for storing the samples at $-20^{\circ} \mathrm{C}$. All samples were divided into two parts, one for soil physical and chemical properties determination, and the other for bacteria isolation and soil DNA extraction.

\section{Soil physicochemical properties determination}

Twenty-seven soil samples with three replicates from 9 sites were collected for analyzing soil physicochemical properties. Soil $\mathrm{pH}$ and $\mathrm{EC}$ were measured at a soil to water ratio of 1:5 (w/v) [25]. STC and STN were determined by Elemental Analyzer (Vario EL III produced by Elementar Analysen System $\mathrm{GmbH}$, Langenselbold, Germany). SOM was determined using the $\mathrm{K}_{2} \mathrm{Cr}_{2} \mathrm{O}_{7}-\mathrm{H}_{2} \mathrm{SO}_{4}$ oxidation method of Walkley-Black [58]. STP was measured by the phosphoric acidmolybdenum-antimony colorimetric method [59]. $\mathrm{K}^{+}$and $\mathrm{Na}^{+}$were determined by flame photometry. Soil texture were measured by Malvern Mastersizer 2000 Laser Particle Size Analyzer [60].

\section{Isolation of cultural bacteria}

For the isolation of soil bacteria, $5 \mathrm{~g}$ soil from each sample was suspended in $45 \mathrm{~mL}$ sterile phosphate-buffered saline (PBS), and agitated on a rotary shaker $(250 \mathrm{rpm})$ for $30 \mathrm{~min}$ at $28^{\circ} \mathrm{C}$. The cultural conditions were chosen based on the ability to support the growth of the most abundance bacteria communities. Four gradient dilutions $\left(10^{-3}, 10^{-4}, 10^{-5}\right.$ and $\left.10^{-6}\right)$ were incubated on $\mathrm{R}_{2} \mathrm{~A}$ [61] in the dark for $5-7$ days at $28^{\circ} \mathrm{C}$, which was finally ascertained by preliminary selection for the condition of cultural bacteria. Colony-forming unit (CFU) per gram of soil dry mass was used to estimate the number of bacteria colonies. The distinct single strain was characterized by streaking methods to get pure colony on the basis of colony morphology analysis, which was further purified three times on $\mathrm{R}_{2} \mathrm{~A}$ agar. All isolates were stored at $-80^{\circ} \mathrm{C}$ in the $\mathrm{R}_{2} \mathrm{~A}$ liquid media containing $20 \%$ glycerol for further use.

\section{DNA extraction and polymerase chain reaction (PCR) amplification}

Culturable bacteria colonies were used for DNA extraction by CTAB procedure $[62,63]$. The $16 \mathrm{~S}$ rDNA genes were amplified from genomic DNA by polymerase chain reaction (PCR, GeneAmp 9700, ABI, USA) using the universal primers 27F (5'-AGAGTTTGATC(A/C)TGGCTCAG-3') and 1492R (5'-GG(C/T)TACCTTGTTACGACTT-3') [64]. PCR amplifications were performed using the following conditions: initial denaturation of template DNA $\left(95^{\circ} \mathrm{C}\right.$ for $3 \mathrm{~min}$ ), then 1 cycle consisting of denaturation ( $30 \mathrm{~s}$ at $\left.94{ }^{\circ} \mathrm{C}\right)$, annealing $\left(30 \mathrm{~s}\right.$ at $\left.55^{\circ} \mathrm{C}\right)$, extension $(1 \mathrm{~min} 40 \mathrm{~s}$ at $72{ }^{\circ} \mathrm{C}$ ), 34 cycles at $94{ }^{\circ} \mathrm{C}$ for $30 \mathrm{~s}, 55^{\circ} \mathrm{C}$ for $30 \mathrm{~s}, 72^{\circ} \mathrm{C}$ for 1 
min $40 \mathrm{~s}$, and a final extension at $72{ }^{\circ} \mathrm{C}$ for $5 \mathrm{~min}$. The culturable bacteria were identified by the $16 \mathrm{~S}$ rDNA genes, and bacteria sequences obtained by culture-depended approach were compared with $16 \mathrm{~S}$ rDNA reference gene sequences by BLAST (http://eztaxon-e:ezbiocloud.net). An equal volume of sterile deionized water in each batch of the PCRs as a negative control. PCR products were checked electrophoretically in a $0.4 \%$ agarose gel. The sequencing work was performed at Beijing Genomics Institute, Beijing, China.

\section{Illumina MiSeq sequencing for culture-independent identification}

Total DNA of bacteria community was extracted from soil samples ( $0.5 \mathrm{~g}$ wet weight) with E.Z.N.A Soil DNA kit (Omega Bio-tek, Norcross, GA, US). The extracted DNA was diluted in TE buffer $(10 \mathrm{mM}$ Tris- $\mathrm{HCl}, 1 \mathrm{mM}$ EDTA, $\mathrm{pH}$ 8.0) and stored at $-20^{\circ} \mathrm{C}$ for further use. An aliquot (50 ng) of purified DNA from each sample was used as template for amplification. We used the $515 \mathrm{~F}$ (5'-GTGCCAGCMGCCGCGG-3') and 907R (5' -CCGT CAATTCMTTTRAGTTT-3') primers to amplify the bacterial 16S rRNA V4-V5 fragments. The barcode-tagged 16S rRNA V4-V5 PCR products were pooled with other samples and sequenced by Illumina Miseq PE250 (Majorbio BioPharm Technology Co., Ltd., Shanghai, China). Every sample was amplified in triplicate with $50 \mathrm{~mL}$ reaction under following conditions: 30 cycles of denaturation at $94{ }^{\circ} \mathrm{C}$ for $30 \mathrm{~s}$, annealing at $55^{\circ} \mathrm{C}$ for $30 \mathrm{~s}$, extension at $72{ }^{\circ} \mathrm{C}$ for $30 \mathrm{~s}$, and a final extension at $72{ }^{\circ} \mathrm{C}$ for $10 \mathrm{~min}$. PCR products checked electrophoretically in a $2 \%$ agarose gel were purified by AxyPrep DNA gel extraction kit (Axygen Biosciences, Union City, CA, USA) and quantified using QuantiFluor ${ }^{\mathrm{rm}}-\mathrm{ST}$ (Promega, USA) according to the manufacturer's protocol. Purified amplicons were pooled in equimolar and paired-end sequenced $(2 \times 300 \mathrm{bp})$ using an Illumina MiSeq platform (Illumina, San Diego, CA, USA) according to the standard protocols of the Majorbio BioPharm Technology Co. Ltd. (Shanghai, China). The pyrosequencing data were analyzed by QIIME version 1.5.0 software pipeline [65]. The raw reads were deposited into the NCBI Sequence Read Archive (SRA) database (Accession Number: SAMN17227076 - SAMN17227102).

\section{MiSeq sequencing data processing and analysis}

All unique sequences from culture-dependent and cultureindependent methods were used to define the number of OTUs with a $97 \%$ similarity cut-off using UPARSE (version $7.1 \mathrm{http}: / /$ drive5.com/uparse/). A randomly selected subset of 10,000 sequences per sample for subsequent community analysis was used to get more reliable survey data. The weighted UniFrac distances calculated for the total community analyses were visualized using non-metric multidimensional scaling (NMDS) plots as implemented in PRIMER
V6 [66]. Canonical correspondence analysis were used to identify the abiotic factors, most important to bacterial community composition, and they were used to construct the sediment property matrix for variation partitioning analysis with Canoco 5.03.LEfSe [67, 68]. NMDS dissimilarity matrix of R Package Version 2.0-10 was applied using the "picante" and "vegan" packages in the $R$ environment [69]. The data is statistically analyzed by factor analysis, reliability analysis, one-way ANOVA, and Pearson's product-moment correlation using SPSS 17.0 for Windows (SPSS Inc., Chicago, USA). A $P$ value less than 0.05 is statistically significant. PCA was performed by CANOCO 4.5 software (Wageningen University and Research Centre, Wageningen, the Netherlands).

\section{Abbreviations}

N.tangutorum: Nitraria tangutorum; H. ammodendron: Haloxylon ammodendron; EC: Electrical conductivity; STC: Soil total carbon; STN: Soil total nitrogen; SOM: Soil organic matter; STP: Soil total phosphorus; AC: Bulk soil without plant from fixed sandy land; BC: Bulk soil without plant from semi-fixed sandy land; CC: Bulk soil without plant from shifting sandy land; AN: N. tangutorum rhizosphere in fixed sandy land; BN: N. tangutorum rhizosphere in semi-fixed sandy land; CN: N. tangutorum rhizosphere in shifting sandy land; $\mathrm{AH}: \mathrm{H}$. ammodendron rhizosphere in fixed sandy land; $\mathrm{BH}$ : $\mathrm{H}$. ammodendron rhizosphere in semi-fixed sandy land; $\mathrm{CH}$ : H. ammodendron rhizosphere in shifting sandy land; CFU: Colony-forming unit; SAC: Species accumulation curve; OTUs: Operational taxonomic units; PCA: Principal component analysis; PBS:

Phosphate-buffered saline; NMDS: Non-metric multidimensional scaling

\section{Supplementary Information}

The online version contains supplementary material available at https://doi. org/10.1186/s12866-021-02150-0.

Additional file 1: Figure S1. Species accumulation curve. Figure S2. Comparison of the relative abundance of the samples through high through-put technology and cultivable way. Table S1. Genetic diversity of culturable plant-associated bacteria from different sites.

Acknowledgements

We are thankful to the anonymous reviewers who helped improve this paper. We are also thankful to Zhenyu Xie from Hainan University for his support in data analysis.

\section{Authors' contributions}

YW, FW and HS designed the experiments. YW, FW, JG and YH performed the experiments. YW, FW, JG, YH and WR analyzed the data and prepared the figures and tables. HS supervised the study and reviewed the manuscript. YW wrote the manuscript. All authors have read and approved the final manuscript.

\section{Funding}

This work was supported by the National Natural Science Foundation of China (grant No. 31570488), the National Program on Key Basic Research Project (973 Program) (grant No. 2013CB429904), Major Special Science and Technology Project of Gansu Province (grant No.17ZD2WA017).

\section{Availability of data and materials}

All data generated or analyzed during this study are included in this published article [and its supplementary information files]. The raw reads of pyrosequencing data have been deposited into the NCBI Sequence Read Archive (SRA) database repository, [https://www.ncbi.nlm.nih.gov/sra] and [Accession Number: SAMN17227076 - SAMN17227102]. 


\section{Declarations}

\section{Ethics approval and consent to participate}

Not applicable.

\section{Consent for publication}

Not applicable.

\section{Competing interests}

The authors declare that they have no known competing financial interests or personal relationships that could have appeared to influence the work reported in this paper.

\section{Author details}

${ }^{1}$ Ministry of Education Key Laboratory of Cell Activities and Stress Adaptations, School of Life Sciences, Lanzhou University, Lanzhou, China. ${ }^{2}$ School of medicine, northwest minzu university, Lanzhou, China. ${ }^{3}$ State Key Laboratory of Marine Resource Utilization in the South China Sea, Hainan University, Haikou, Hainan Province, China.

Received: 23 November 2020 Accepted: 8 March 2021

Published online: 22 March 2021

\section{References}

1. Reynolds JF, Smith DMS, Lambin EF, Turner B, Mortimore M, Batterbury SP, Downing TE, Dowlatabadi H, Fernández RJ, Herrick JE. Global desertification: building a science for dryland development. Science. 2007;316(5826):84751. https://doi.org/10.1126/science.1131634.

2. Veron S, Paruelo J, Oesterheld M. Assessing desertification. J Arid Environ. 2006;66(4):751-63. https://doi.org/10.1016/j.jaridenv.2006.01.021.

3. Huang J, Zhang G, Zhang Y, Guan X, Wei Y, Guo R. Global desertification vulnerability to climate change and human activities. Land Degrad Dev. 2020;31(11):1380-91. https://doi.org/10.1002/ldr.3556.

4. Zhang Y, Cao C, Han X, Jiang S. Soil nutrient and microbiological property recoveries via native shrub and semi-shrub plantations on moving sand dunes in Northeast China. Ecol Eng. 2013;53:1-5. https://doi.org/10.1016/j. ecoleng.2013.01.012.

5. Li K, Liu R, Zhang H, Yun J. The diversity and abundance of bacteria and oxygenic phototrophs in saline biological desert crusts in Xinjiang. Northwest China Microb Ecol. 2013;66(1):40-8. https://doi.org/10.1007/s0024 8-012-0164-1.

6. Du J, Yan P, Dong Y. Phenological response of Nitraria tangutorum to climate change in Minqin County, Gansu Province, Northwest China. Int J Biometeorol. 2010;54(5):583-93. https://doi.org/10.1007/s00484-010-0315-3.

7. Eriksson M. Afforestation and avoided deforestation in a multi-regional integrated assessment model. Ecol Econ. 2020;169:106452. https://doi.org/1 0.1016/j.ecolecon.2019.106452.

8. Fernandes GW, Coelho MS, Machado RB, Ferreira ME, de Souza Aguiar LM, Dirzo R, Scariot A, Lopes CR. Afforestation of savannas: an impending ecological disaster. Nat Conservacao. 2016;14(2):146-51. https://doi.org/10.1 016/j.ncon.2016.08.002.

9. Li XR, Ma FY, Xiao HL, Wang XP, Kim KC. Long-term effects of revegetation on soil water content of sand dunes in arid region of northern China. J Arid Environ. 2004:57(1):1-16. https://doi.org/10.1016/S0140-1963(03)00089-2.

10. Sohng J, Singhakumara BMP, Ashton MS. Effects on soil chemistry of tropical deforestation for agriculture and subsequent reforestation with special reference to changes in carbon and nitrogen. For Ecol Manag. 2017; 389:331-40. https://doi.org/10.1016/j.foreco.2016.12.013.

11. Kassa H, Dondeyne S, Poesen J. Frankl A, Nyssen J. Impact of deforestation on soil fertility, soil carbon and nitrogen stocks: the case of the Gacheb catchment in the White Nile Basin. Ethiopia Agr Ecosyst Environ. 2017;247: 273-82. https://doi.org/10.1016/j.agee.2017.06.034.

12. Pontes PRM, Cavalcante RBL, Sahoo PK, da silva Junior RO, da Silva MS, Dall'Agnol R, Siqueira JO. The role of protected and deforested areas in the hydrological processes of Itacaiunas River Basin, eastern Amazonia. J Environ Manag. 2019;235:489-99. https://doi.org/10.1016/j.jenvman.2019.01.090.

13. Sambe LN, Adeofun CO, Dachung G. The economic and ecological effects of deforestation on the Nigerian environment. Asian J Adv Res Rep. 2018:125. https://doi.org/10.9734/ajarr/2018/v1i213038.

14. Pv G, Van Veen J, Van Elsas J. Microbial diversity in soil: selection of microbial populations by plant and soil type and implications for disease suppressiveness. Annu Rev Phytopathol. 2004;42(1):243-70. https://doi.org/1 0.1146/annurev.phyto.42.012604.135455.

15. Prestel E, Regeard C, Salamitou S, Neveu J, DuBow MS. The bacteria and bacteriophages from a Mesquite flats site of the Death Valley desert. Antonie Van Leeuwenhoek. 2013;103(6):1329-41. https://doi.org/10.1007/s1 0482-013-9914-4.

16. Krishna P, Babu AG, Reddy MS. Bacterial diversity of extremely alkaline bauxite residue site of alumina industrial plant using culturable bacteria and residue 165 rRNA gene clones. Extremophiles. 2014;18(4):665-76. https://doi. org/10.1007/s00792-014-0647-8

17. Pérez-Fernández MA, Calvo-Magro E, Valentine A. Benefits of the symbiotic association of shrubby legumes for the rehabilitation of degraded soils under Mediterranean climatic conditions. Land Degrad Dev. 2016;27(2):395405. https://doi.org/10.1002/ldr.2457.

18. Andrew DR, Fitak RR, Munguia-Vega A, Racolta A, Martinson VG, Dontsova K. Abiotic factors shape microbial diversity in Sonoran Desert soils. Appl Environ Microbiol. 2012;78(21):7527-37. https://doi.org/10.1128/AEM.01459-12.

19. Tian Q, Taniguchi T, Shi W-Y, Li G, Yamanaka N, Du S. Land-use types and soil chemical properties influence soil microbial communities in the semiarid loess plateau region in China. Sci Rep. 2017;7(1):45289. https://doi. org/10.1038/srep45289.

20. Liu Y, Zhang L, Lu J, Chen W, Wei G, Lin Y. Topography affects the soil conditions and bacterial communities along a restoration gradient on loessplateau. Appl Soil Ecol. 2020;150:103471. https://doi.org/10.1016/j.apsoil.201 9.103471.

21. Yuanyuan $Y$, Yin Z, Zhou S, Rossel RAV, Liang Z, Haizhen W, Lianqing Z, Wu $Y$. Interactive effects of elevation and land use on soil bacterial communities in the Tibetan plateau. Pedosphere. 2020;30(6):817-31. https://doi.org/10.101 6/S1002-0160(19)60836-2.

22. Vieira S, Sikorski J, Dietz S, Herz K, Schrumpf M, Bruelheide H, Scheel D, Friedrich MW, Overmann J. Drivers of the composition of active rhizosphere bacterial communities in temperate grasslands. ISME J. 2020;14(2):463-75. https://doi.org/10.1038/s41396-019-0543-4.

23. Feeser KL, Van Horn DJ, Buelow HN, Colman DR, McHugh TA, Okie JG, Schwartz E, Takacs-Vesbach CD. Local and regional scale heterogeneity drive bacterial community diversity and composition in a polar desert. Front Microbiol. 2018;9:1928. https://doi.org/10.3389/fmicb.2018.01928.

24. Kim JM, Roh A-S, Choi S-C, Kim E-J, Choi M-T, Ahn B-K, Kim S-K, Lee Y-H, Joa $\mathrm{J}-\mathrm{H}$, Kang S-S. Soil pH and electrical conductivity are key edaphic factors shaping bacterial communities of greenhouse soils in Korea. J Microbiol. 2016;54(12):838-45. https://doi.org/10.1007/s12275-016-6526-5.

25. Cai M, Peng $X$, Cheng $X$, Liu L, Xing S, Shang T, Han H. Soil element stoichiometry drives bacterial community composition following thinning in a larix plantation in the subalpine regions of northern China. Forests. 2020; 11(3):261. https://doi.org/10.3390/f11030261.

26. Liu J, Sui Y, Yu Z, Shi Y, Chu H, Jin J, Liu X, Wang G. High throughput sequencing analysis of biogeographical distribution of bacterial communities in the black soils of Northeast China. Soil Biol Biochem. 2014; 70:113-22. https://doi.org/10.1016/j.soilbio.2013.12.014.

27. Beneduzi A, Moreira F, Costa PB, Vargas LK, Lisboa BB, Favreto R, Baldani J, Passaglia LMP. Diversity and plant growth promoting evaluation abilities of bacteria isolated from sugarcane cultivated in the south of Brazil. Appl Soil Ecol. 2013;63:94-104. https://doi.org/10.1016/j.apsoil.2012.08.010.

28. Ni J, Wu X, Zhang H, Liu T, Zhang L. Comparative analysis of salt tolerance of three Nitraria species. For Res. 2012;25(2):48-53. https://doi.org/10.1007/ s11783-011-0280-Z.

29. Stomeo F, Valverde A, Pointing SB, McKay CP, Warren-Rhodes KA, Tuffin MI, Seely M, Cowan DA. Hypolithic and soil microbial community assembly along an aridity gradient in the Namib Desert. Extremophiles. 2013;17(2): 329-37. https://doi.org/10.1007/s00792-013-0519-7.

30. Liu X, He Y, Zhao X, Zhang T, Li Y, Yun J, Wei S, Yue X. The response of soil water and deep percolation under Caragana microphylla to rainfall in the Horqin sand land, northern China. Catena. 2016;139:82-91. https://doi.org/1 0.1016/j.catena.2015.12.006

31. Chen L, Wang J, Wei W, Fu B, Wu D. Effects of landscape restoration on soil water storage and water use in the loess plateau region. China For Ecol Manage. 2010;259(7):1291-8. https://doi.org/10.1016/j.foreco.2009.10.025.

32. Kavamura VN, Taketani RG, Lançoni MD, Andreote FD, Mendes R, de Melo IS. Water regime influences bulk soil and rhizosphere of Cereus jamacaru bacterial communities in the Brazilian Caatinga biome. PLoS One. 2013;8(9): e73606. https://doi.org/10.1371/journal.pone.0073606. 
33. McCaig AE, Glover LA, Prosser JI. Molecular analysis of bacterial community structure and diversity in unimproved and improved upland grass pastures. Appl Environ Microbiol. 1999;65(6):1721-30. https://doi.org/10.1016/S0003-4 975(02)04832-4

34. Fazi S, Amalfitano S, Pernthaler J, Puddu A. Bacterial communities associated with benthic organic matter in headwater stream microhabitats. Environ Microbiol. 2005;7(10):1633-40. https://doi.org/1 0.1111/j.1462-2920.2005.00857.x.

35. Fierer N, Bradford MA, Jackson RB. Toward an ecological classification of soil bacteria. Ecology. 2007;88(6):1354-64. https://doi.org/10.1890/05-1839.

36. Dion P. Extreme views on prokaryote evolution. Microbiol Extreme Soils. 2008:45-70. https://doi.org/10.1007/978-3-540-74231-9_3.

37. Philippot L, Andersson SG, Battin TJ, Prosser JI, Schimel JP, Whitman WB, Hallin S. The ecological coherence of high bacterial taxonomic ranks. Nat Rev Microbiol. 2010;8(7):523-9. https://doi.org/10.1038/nrmicro2367.

38. Bardhan S, Jose S, Jenkins MA, Webster CR, Udawatta RP, Stehn SE. Microbial community diversity and composition across a gradient of soil acidity in spruce-fir forests of the southern Appalachian Mountains. Appl Soil Ecol. 2012;61:60-8. https://doi.org/10.1016/j.apsoil.2012.04.010.

39. Cregger MA, Schadt CW, McDowell NG, Pockman WT, Classen AT. Response of the soil microbial community to changes in precipitation in a semiarid ecosystem. Appl Environ Microbiol. 2012;78(24):8587-94. https://doi.org/1 0.1128/AEM.02050-12.

40. Wieland G, Neumann R, Backhaus H. Variation of microbial communities in soil, rhizosphere, and rhizoplane in response to crop species, soil type, and crop development. Appl Environ Microbiol. 2001;67(12):5849-54. https://doi. org/10.1128/AEM.67.12.5849-5854.2001.

41. Kowalchuk GA, Buma DS, de Boer W, Klinkhamer PG, van Veen JA. Effects of above-ground plant species composition and diversity on the diversity of soil-borne microorganisms. Antonie Van Leeuwenhoek. 2002;81(1):509-20. https://doi.org/10.1023/A:1020565523615.

42. Salles JF, Van Veen JA, Van Elsas JD. Multivariate analyses of Burkholderia species in soil: effect of crop and land use history. Appl Environ Microbiol. 2004;70(7):4012-20. https://doi.org/10.1128/AEM.70.7.4012-4020.2004.

43. Wei Y, Bu J, Long H, Zhang X, Cai X, Huang A, Ren W, Xie Z. Community structure of protease-producing bacteria cultivated from aquaculture systems: potential impact of a tropical environment. Front Microbiol. 2021; 12. https://doi.org/10.3389/fmicb.2021.638129.

44. Amann Rl, Ludwig W, Schleifer K-H. Phylogenetic identification and in situ detection of individual microbial cells without cultivation. Microbiol Rev. 1995;59(3):143-69. https://doi.org/10.1016/S0882-4010(95)90076-4.

45. Zhang L, Zhang Q, Luo X, Tang Y, Dai J, Li Y, Wang Y, Chen G, Fang C. Pontibacter korlensis sp. nov., isolated from the desert of Xinjiang, China. Int J Syst Evol Microbiol. 2008;58(5):1210-4. https://doi.org/10.1099/ijs.0.65667-0.

46. Nocker A, Burr M, Camper AK. Genotypic microbial community profiling: a critical technical review. Microb Ecol. 2007;54(2):276-89. https://doi.org/10.1 007/s00248-006-9199-5.

47. Han J, Song Y, Liu Z, Hu Y. Culturable bacterial community analysis in the root domains of two varieties of tree peony (Paeonia ostii). FEMS Microbiol Lett. 2011;322(1):15-24. https://doi.org/10.1111/j.1574-6968.2011.02319.x.

48. Wang X-D, Qiu S-Y, Li P, Ban S-D. Analysis of microbial community structure in traditional and automated Moutai-flavor Daqu. J Am Soc Brew Chem. 2019;77(2):140-6. https://doi.org/10.1080/03610470.2019.1569886.

49. Ryan RP, Germaine K, Franks A, Ryan DJ, Dowling DN. Bacterial endophytes: recent developments and applications. FEMS Microbiol Lett. 2008;278(1):1-9. https://doi.org/10.1111/j.1574-6968.2007.00918.x.

50. Nilsson RH, Anslan S, Bahram M, Wurzbacher C, Baldrian P, Tedersoo L. Mycobiome diversity: high-throughput sequencing and identification of fungi. Nat Rev Microbiol. 2019;17(2):95-109. https://doi.org/10.1038/s41579018-0116-y

51. Anguita-Maeso M, Olivares-Garcia C, Haro C, Imperial J, Navas-Cortes JA, Landa BB. Culture-dependent and culture-independent characterization of the olive xylem microbiota: effect of sap extraction methods. Front Plant Sci. 2020;10. https://doi.org/10.3389/fpls.2019.01708.

52. Buee M, Reich M, Murat C, Morin E, Nilsson R, Uroz S, Martin F. 454 pyrosequencing analyses of forest soils reveal an unexpectedly high fungal diversity. New Phytol. 2009;184(2):449-56. https://doi.org/10.1111/j.1469-813 7.2009.03003.x.

53. Chen YG, Cui XL, Kroppenstedt RM, Stackebrandt E, Wen ML, Xu LH, Jiang CL. Nocardiopsis quinghaiensis sp. nov., isolated from saline soil in China. Int J Syst Evol Microbiol. 2008;58(3):699-705. https://doi.org/10.1099/ijs.0.65441-0.
54. Joung Y, Kim H, Ahn TS, Jon K. Pontibacter salisaro sp. nov., isolated from a clay tablet solar saltern in Korea. J Microbiol. 2011;49:290. https://doi.org/1 0.1007/s12275-011-0093-6.

55. Nacke H, Thürmer A, Wollherr A, Will C, Hodac L, Herold N, Schöning I, Schrumpf M, Daniel R. Pyrosequencing-based assessment of bacterial community structure along different management types in German forest and grassland soils. PLoS One. 2011;6(2):e17000. https://doi.org/10.1371/ journal.pone.0017000.

56. Shen C, Xiong J, Zhang H, Feng Y, Lin X, Li X, Liang W, Chu H. Soil pH drives the spatial distribution of bacterial communities along elevation on Changbai Mountain. Soil Biol Biochem. 2013;57:204-11. https://doi.org/10.1 016/j.soilbio.2012.07.013.

57. Gao J, Luo $Y$, Wei $Y$, Huang $Y$, Zhang H, He W, Sheng H, An L. Screening of plant growth promoting bacteria (PGPB) from rhizosphere and bulk soil of Caragana microphylla in different habitats and their effects on the growth of Arabidopsis seedlings. Biotechnol Biotechnol Equip. 2019;33(1):921-30. https://doi.org/10.1080/13102818.2019.1629841.

58. De Vos B, Lettens S, Muys B, Deckers JA. Walkley-black analysis of forest soil organic carbon: recovery, limitations and uncertainty. Soil Use Manag. 2007; 23(3):221-9. https://doi.org/10.1111/j.1475-2743.2007.00084.x.

59. Murphy J, Riley JP. A modified single solution method for the determination of phosphate in natural waters. Anal Chim Acta. 1962;27:678-81. https://doi. org/10.1016/S0003-2670(00)88444-5.

60. Sochan A, Bieganowski A, Ryzak M, Dobrowolski R, Bartminski P. Comparison of soil texture determined by two dispersion units of Mastersizer 2000. Int Agrophys. 2012;26(1):99-102. https://doi.org/10.2478/v1 0247-012-0015-9.

61. Reasoner DJ, Geldreich EE. A new medium for the enumeration and subculture of bacteria from potable water. Appl Environ Microbiol. 1985; 49(4):1-7. https://doi.org/10.1016/0141-4607(85)90029-0.

62. Sun L, Qiu F, Zhang X, Dai X, Dong X, Song W. Endophytic bacterial diversity in rice (Oryza sativa L.) roots estimated by $16 \mathrm{~S}$ rDNA sequence analysis. Microb Ecol. 2008;55:415-24. https://doi.org/10.1007/s00248-007-9287-1.

63. Marquez-Santacruz HA, Hernandez-Leon R, Orozco-Mosqueda MC, Velazquez-Sepulveda I, Santoyo G. Diversity of bacterial endophytes in roots of Mexican husk tomato plants (Physalis ixocarpa) and their detection in the rhizosphere. Genet Mol Res. 2010;9(4):2372-80. https://doi.org/10.4238/ vol9-4gmr921.

64. Mishra PK, Bisht SC, Ruwari P, Selvakumar G, Joshi GK, Bisht JK, Bhatt JC, Gupta HS. Alleviation of cold stress in inoculated wheat (Triticum aestivum L. ) seedlings with psychrotolerant Pseudomonads from NW Himalayas. Arch Microbiol. 2011;193:497-513. https://doi.org/10.1007/s00203-011-0693-X.

65. Caporaso JG, Kuczynski J, Stombaugh J, Bittinger K, Bushman FD, Costello EK, Fierer N, Pena AG, Goodrich JK, Gordon Jl. QIIME allows analysis of highthroughput community sequencing data. Nat Methods. 2010;7(5):335-6. https://doi.org/10.1038/nmeth.f.303.

66. Clarke K, Warwick R. A further biodiversity index applicable to species lists: variation in taxonomic distinctness. Mar Ecol Prog Ser. 2001;216:265-78. https://doi.org/10.3354/meps216265.

67. Segata N, Izard J, Waldron L, Gevers D, Miropolsky L, Garrett WS, Huttenhower C. Metagenomic biomarker discovery and explanation. Genome Biol. 2011;12(6):1-18. https://doi.org/10.1186/gb-2011-12-6-r60.

68. Lai J. Canoco 5: a new version of an ecological multivariate data ordination program. Biodivers Sci. 2013;21(6):765-8. https://doi.org/10.3724/SP.J.1003.2 013.04133.

69. Jari O, F. Guillaume B, Michael F, Roeland K, Pierre L, Dan M, Peter RM, O'Hara RB, Gavin LS, Peter S, et al: Vegan: community ecology package. R Package Version 2.0-10. http://CRAN.R-project.org/package=vegan; 2013.

\section{Publisher's Note}

Springer Nature remains neutral with regard to jurisdictional claims in published maps and institutional affiliations. 